\title{
Commentary
}

HORMONE

RESEARCH IN

Published online: March 6, 2015

PAEDIATRICS

DOI: $10.1159 / 000374114$

\section{How Aggressively Should We Treat Short Stature?}

\author{
Ron G. Rosenfeld \\ Oregon Health and Science University, Portland, Oreg., and STAT5 LLC, Los Altos, Calif., USA
}

Growth hormone (GH) has been used for the treatment of GH deficiency (GHD) for over 50 years. With the development of recombinant DNA-derived GH in the early 1980s, the essentially unlimited supply of GH facilitated expansion of pediatric indications to many other forms of short stature, including idiopathic short stature, Turner syndrome, small for gestational age infants, Noonan syndrome and Prader-Willi syndrome, to name a few. In general, these other conditions, while typically displaying accelerated growth when treated with exogenous $\mathrm{GH}$, did not show as robust a response to $\mathrm{GH}$ therapy as that observed in children with GHD.

For $\mathrm{GH}$ to act, it must bind to a transmembrane dimeric receptor and initiate a signaling cascade(s) culminating in the production of insulin-like growth factor-I (IGF-I), primarily from liver, but also from a variety of other tissues [1]. Children with molecular defects of genes for the growth hormone receptor or for signal transducer and activator of transcription $5 \mathrm{~b}$ (STAT5b), a critical part of the GH-signaling cascade, have auxologic characteristics essentially identical to congenital GHD, but are unresponsive to GH therapy [2]. In such cases, the molecular defect can be 'bypassed' through the use of IGF-I therapy, although the growth response in such cases is typically less than that observed with GH treatment of GHD $[3,4]$.

A rationale for the combination GH plus IGF-I therapy has several lines of support: (1) GH activates several postreceptor-signaling cascades, and it has been suggested that not all of GH's growth-promoting actions are me-
(C) 2015 S. Karger AG, Base

$1663-2818 / 15 / 0834-0280 \$ 39.50 / 0$ diated through the STAT5b-IGF-I pathway [5]; (2) the response to systemically administered IGF-I might be enhanced by GH-induced local IGF-I production at key target tissues; (3) in addition to stimulating production of IGF-I, GH treatment increases serum concentrations of IGF binding protein-3 and acid-labile subunit, carrier proteins for the IGFs that also serve to increase the halflife of IGFs in serum; (4) the 'diabetogenic' actions of GH and the insulin-like actions of IGF-I could balance each other, thereby mitigating both glucose intolerance and hypoglycemia; (5) studies of the growth and IGF responses of idiopathic short stature children treated with GH have suggested some degree of both GH and IGF resistance in many such patients [6], and (6) animal studies have indicated an additive growth response in rodents treated with combination GH plus IGF-I [7].

The paper by Backeljauw et al. [8] describes the first study to test the efficacy and safety of combination GH plus IGF-I in children with short stature and, as such, provides important insights into the potential utility and limitations of such an approach. The study group was, essentially, an idiopathic short stature population characterized by serum IGF-I concentrations below $-1 \mathrm{SD}$. When compared with the group receiving $\mathrm{GH}$ alone, only subjects in group $\mathrm{D}$ (GH plus the highest dosage of IGF-I) showed a significant increase in growth velocity, but this was modest and only seen in year 1 . Over the 3-year trial period, the cumulative change in height SD score was 1.9 in group $\mathrm{D}$, compared to 1.3 in the $\mathrm{GH}$-alone group. As expected, subjects receiv-
KARGER 125\%

E-Mail karger@karger.com www.karger.com/hrp
Prof. emeritus Ron G. Rosenfeld, MD

STAT5, LLC, PO Box 1746

Los Altos, CA 94023 (USA)

E-Mail ron@stat5consulting.com 
ing combination treatment experienced dramatic elevations in serum IGF-I, necessitating dose reductions for IGF-I serum concentrations greater than $+4 \mathrm{SD}$.

How are we to interpret these results and what are the implications for therapy in short stature? We must, first of all, recognize that this is an important investigation, with a legitimate theoretical rationale. At the same time, the study has several significant limitations: (1) the GH-alone group received a relatively high $\mathrm{GH}$ dosage $(45 \mu \mathrm{g} / \mathrm{kg} /$ day); an additive effect with IGF-I might have been more dramatic at lower GH dosages; (2) the study suffers from the lack of a subject group receiving IGF-I alone; (3) the potential benefit of combination therapy may have been masked by a protocol that required lowering dosages (understandably, perhaps) when serum IGF-I concentrations were deemed to be unacceptably high, and (4) molecular studies were not performed, and it is possible that some of the subjects had unrecognized genetic defects impacting their responsiveness to either GH or IGF-I.
Still, one is forced to conclude that the benefits of combination therapy, in this population and at the dosages employed, do not support the generalized use of combination GH plus IGF-I. The additional growth response observed with combination therapy was too modest to justify sustained elevations of IGF-I well beyond the normal range in otherwise healthy children (although it is important to note that adverse effects related to therapeutically elevated serum IGF-I concentrations have never been demonstrated). There may be select cases, however, where a trial of combination therapy might be justified, as in patients in whom the opposing metabolic actions of GH and IGF-I are desirable (patients who are prone to glucose intolerance with GH treatment, for example) or, perhaps, in patients who appear to be refractory to $\mathrm{GH}$ therapy. In such cases, serum IGF-I concentrations should be monitored with care and any potential growth benefit weighed against safety concerns, both real and theoretical.

\section{References}

1 Rosenfeld RG, Hwa V: The growth hormone cascade and its role in mammalian growth Horm Res 2009;71(suppl 2):36-40.

-2 David A, Hwa V, Metherell LA, Netchine I, Camacho-Hubner C, Clark AJL, Rosenfeld RG, Savage MO: Evidence for a continuum of genetic, phenotypic and biochemical abnormalities in children with growth hormone insensitivity. Endocr Rev 2011;32:472-497.

3 Chernausek SD, Backeljauw PF, Frane J, Kuntze J, Underwood LE: Long-term treatment with recombinant insulin-like growth factor (IGF)-I in children with IGF-I deficiency due to growth hormone insensitivity. J Clin Endocrinol Metab 2007;92:902-910.
4 Guevara-Aguirre J, Rosenbloom AL, Vasconez O, Martinez V, Gargosky SE, Rosenfeld RG: Two-year treatment of growth hormone receptor deficiency (GHRD) with recombinant insulin-like growth factor-I in 22 children: comparison of two dosage levels and to GH-treated GH deficiency. J Clin Endocrinol Metab 1997;82:629-633.

5 Le Roith D, Bondy C, Yakar S, Liu JL, Butler A: The somatomedin hypothesis: 2001. Endocr Rev 2001;22:53-74.

6 Cohen P, Rogol AD, Howard CP, Bright GM, Kappelgaard AM, Rosenfeld RG: Insulin-like growth factor-based dosing of growth hormone therapy in children: a randomized, controlled study. J Clin Endocrinol Metab 2007; 92:2480-2486.
7 Clark RG, Carlsson LM, Mortensen D, Cronin MJ: Additive effects on body growth of insulin-like growth factor-I and growth hormone in hypophysectomized rats. Endocrinol Metab 1994;1:49-54.

8 Backeljauw PF, Miller BS, Dutailly P, Houchard A, Lawson E, Hale DE, Reiner B, Sperling MA; on behalf of the MS316 Study Group: Recombinant human growth hormone plus recombinant human insulin-like growth factor-1 coadministration therapy in short children with low insulin-like growth factor-1 and growth hormone sufficiency: results from a randomized, multicenter, open-label, parallel-group, active treatment-controlled trial. Horm Res Paediatr DOI: 10.1159/000371799. 